A Journal of Culture, English Language, Teaching $\&$ Literature

ISSN 1412-3320 (Print), ISSN 2502-4914(Online)

Vol. 16 No. 2; December 2016

Copyright @ Soegijapranata Catholic University, Indonesia

\title{
EXPLORING STUDENTS' PERCEPTION AND ICT USE IN INDONESIAN HIGH SCHOOLS
}

Antonius Suratno \& Emilia Ninik Aydawati

English Department, Faculty of Language and Arts,

Soegijapranata Catholic University, Indonesia

$\mathrm{Ph}$ :

$+6282136580717$

Email:

+62 87832426180

antono.dito@gmail.com

emilianinik@gmail.com

Received: 10-11-2016

Accepted: 23-02-2017

Published: 28-02-2017 


\title{
EXPLORING STUDENTS' PERCEPTION AND ICT USE IN INDONESIAN HIGH SCHOOLS
}

\author{
Antonius Suratno and Emilia Ninik Aydawati \\ antono.dito@gmail.com; emilianinik@gmail.com \\ English Department, Faculty of Language and Arts, \\ Soegijaparanata Catholic University, Semarang, Indonesia
}

\begin{abstract}
The recent spread of technological innovation along with the sophistication of the ICT gadgets have shapped and transformed the realm of learning and teaching including in that of English Language. Alongside, ICT has become more and more inextricable part of human businesses and put a higher level of demand for technological literacy in the part of English learners in order for them to be convident in the digital era membership and participation. This study surveyed 400 high school students as regards: (a) their ICT gadgets perceived ownership; (b) their dayto-day outside and in-school use and; (c) their activities using ICT gadgets for English learning. Findings from the descriptive analyses of the mixed-method study, disclose the positive perception about the gadget ownership. Interestingly, the current study also discovers that there has been a mismatch between the positively perceived ownership of the ICT gadgets and the real day-to-day use as facilitative media for learning, in particular as a useful aids for English language learning. Focusing on the result discussion, issues with regard to discrepancies in the provision of infrastructures and the lack of the support system by school institutions emerge from the FGD analysis highlighting the importance for all decision makers, school institutions, and teachers to consciously start doing something about it. By highlighting the pivotal role of the technology, the researcher suggested a real action for responding to the call for a change in both policy makers and institutonal levels to start integrating the technology into the school curricula.
\end{abstract}

Key words: ICT, ICT-based learning activities, integration, media for learning, support system, language learning 
178 Celt, Volume 16, Number 2, December 2016, pp. 177-200

\begin{abstract}
Abstrak: Inovasi teknologi terkini dengan kecanggihan perangkatnya telah membentuk dan mengubah dunia pengajaran dan pembelajaran termasuk dalam belajar Bahasa Inggris. Bersamaan dengan itu, ICT semakin tidak terpisahkan dengan urusan manusia dan memberikan tuntutan yang kian tinggi terhadap literasi teknologi pada para pembelajar Bahasa Inggris agar mereka semakin percaya diri dalam keikutsertaannya di era digital. Penelitian ini mensurvei 400 siswa sekolah menegah mengenai: (a) pandangan mereka tentang kepemilikan perangkat TIK; (b) pengunaanya di dalam dan di luar lingkungan sekolah dan; (c) aktivitas mereka mengunakan perangkat TIK untuk belajar Bahasa Inggris. Temuan dari analisis diskriptif menggunakan metode campuran ini menunjukkan bahwa responden berpandangan positif. Menariknya, penelitian ini juga menemukan bahwa terdapat ketidaksesuaian antara pandangan positif dengan penggunaan perangkat TIK sebagai media belajar khususnya dalam membantu belajar Bahasa Inggris. Memperhatikan hasil analisis, persoalan bekenaan dengan keberadaan infrastruktur dan sistem pendukung yang masih kurang baik terungkap melalui diskusi terfokus (FGD) sehingga memberikan implikasi pada pentingnya para pemangku kebijakan, institusin sekolah, dan para guru untuk segera mengambil langkah memperbaiki kebijakan dan memulai mengintegrasikan TIK ke dalam kurikulum pengajarn Bahasa Inggris.
\end{abstract}

Kata kunci: ICT, aktivitas berbasis TIK, integrasi, media belajar, sistem pendukung, belajar bahasa

\title{
INTRODUCTION
}

Since the last two decades, the ever advancing information and communication technology has played a prominant role in all aspects of human businesses. There is no denial that every sector of people's day-to-day life has been facilitated by the capabilities that the technology has offered. As a result, every country invests substantial amount of money to catch up with the most recent technologies. In the name of conpetitiveness in the global and regional free market environments, countries down to smaller individual establishments allocate enormous amount of budgets and resources for technological investment. Despite being rather late in its adoption of technology, education as one of the human businesses, slowly join investing efforts and fundings in the provision of ICT for quality of learning and teaching. For some, such an effort is genuinely motivated by the need to let the students and teachers explore the optimal learning and teaching, whilst for 
others, this maybe only to keep up with the most basic requirement for technological literacy as set by the national standard of curriculum which likely remains lacking visions of ICT use and implementational guidelines.

In a relatively short span of time, ICT has evolved in an unprecedented speed. For the case of Indonesia, from year to year the Internet users have multiplied significantly. Based on the data in 2014 the Internet users in Indonesia was 83.7 million people (Ministery of Communication and Information, 2014) and the number has leaped to more than $50 \%$ in 2016 reaching a new record of 130 million in 2016 (Kompas.com, Monday, 24 Oktober 2016). In addition, in the national policy, ICT has been viewed to be a key to improving efficiency process and to reaching competitiveness and that in the educational policy, it is realized that students are confronted by the rapid change. Therefore, schools have to be able to produce competitive human resources ready for competing in the global encounter and to do so, it is believed that ICT inclusion into school curriculum is the answer.

As we know that almost all electronic gadgets now provide choices of application programmes, such as the Internet, audio-video, games, smart facilities, and a lot more has revolved since the early 1980s (see Warschauer and Heale, 1998). What is more, the sophistication of hardwares and sofwares has made it a lot easier to use for various day-to-day uses including for that of learning activities. Although most technological gadgets were not primarily designed and manufactured for language learning, there is a growing optimism that they are potentially useable for learning assistance, not to mention for learning language.

Scholars have also attempted to study the effect of ICT on students' learning by asking why and how multi-media enhanced help options are presented and what effect it has on learning (Rüschoff, 1993). Despite the lack of evidence of the conslusive effect of technology on quality of learning and teaching and although various research has shown that the increased use or availability of ICTs in the classroom does not necessarily result in learning and tranform it into a guaranteed success, ICT must now be regarded as an accepted and proven addition to the existing set of learning media. A large number of tools for a wide variety of applications (viz. Internet, computer, mobile phone and audio-video) have been developed over the past decade, and both standard hardware and software have unprecedentedly become available not only to the privileged few but also to the common members of society for various purposes of learning. All that has been a general consent is that the use 
of technology to facilitate learning is accepted to be of value across educational institutions, such as high school levels.

In this very recent era, ICT has a lot to offer as manifest in the multitude of resources available to access both off and online readily exploitable for teaching and learning purposes, and previous research such as Rüschoff |(1993), indicates that multi-media provide more options for learning and they can affect the results of learning. There are also highlights of acknowledgement that ICT, in the ever advancing multi-media facilities, has been viewed as an inseparable part of humans' life and has been widely acknowleged to be facilitative and mediating for learning, in particular where it has greater potentials for quality of learning. Given the evidence, technological advancement can be driven to gear up and expedite educational change and reform in educational system, in particular where learning-teaching in the most parts of this nation is still very much conservative and lack of innovation resulted from disparities of qualities and inequal resource distribution.

Despite the growing number of users, in the context global and regional competitiveness, Indonesia is currently behind some other countries, even among the closest neighbouring countries in south east asian region. There should be reasons why substantial amount of potential that ICT has for learning alongside the ubiquitous availability of technological gadgets does not necessarily result in optimal learning results. Attempt, therefore, must be made to start doing something about it and one of which is by surveying the users of the ICT gadgets for educational purposes. Among the relevant subjects to be surveyed are students of high schools as regards the ICT gadgets ownership. Issues that may be addreassed are, among other things, how learners or students perceive the use of the technology for the assistance of learning; whether they have used it in positive and productive ways for learning purposes; also if they have taken advantage of it for use of language learning. Therefore, the purpose of this study is to understand how technology is perceived and for what language learning-related activities the ICT have so far been used inside and outside classroom contexts, as well as if it has been exploited for English language learning. 


\section{LITERATURE REVIEW}

\section{A. Perception and Belief in Learning}

Overall, perception may be defined as a process of perceiving something as a result of a reaction to a stimulus on an individual person after having used his or her sensory to react to it and the result of which is an interpretation or identification of the perceived objects. (cf. Robbins, 2003, p. 160). Perception links the external stimuli with the preceived objects based on each individual person experience that produces a unique meaning of the perceived objects. Based on that, he or she can create meanings out of them. (Walgito, 1991, p. 11). This is in line with Branca (in Walgito, 1991, p. 54) that perception serves as a process of organizing and interpreting stimulus in order to create a new meaning of the perceived objects. From the available references, perception is closely liked to beliefs since something is only considered right when it is perceived right as well (Benson \& Lor, 1999).

Beliefs that learning will be successful can be garnered from the past experiences, education, cultural backgrounds, as well as own true personality. Unfortunately, such a linkage is not easily established due to its dynamic and situational natures. Also, the exact relation between perception or beliefs and the success of learning is hard to establish. Yet, there has been a common agreement that they are indirectly connectable to each other, in particular in their positive impact on strategies of learning (Ellis, 2008).

\section{B. Why ICT}

People have generally agreed that ICT has a capacity to allow access to information in faster, more efficient, and effective ways. The wealth of resources available which are accessible through different gadgets of ICT increases the learners' opportunities to discover the world. Besides, research indicates that human perceptions about technologies determine their attitudes towards them (Aviram\&Tami, 2004). Discovery and problem solving which characterize the act of good learning are very compatible with the above nature of ICT. Learning process, therefore, may well be optimized should it be properly directed by people competent of using ICT. Through it, students may be guided to discover learning topics and solutions to problems (Brush, Glazewski and Hew, 2008). Based on previous study (Castro Sánchez and Alemán 2011), students are now generally more viable to access the quality 
data critically and to use relevant information for use of learning selectively, meaning that given a conducive learning environment, students must be able to perform a lot faster.

The plentiful and rich resources for learning coming with the ICT gadgets offer almost limitless options for learning. Teachers of these days are the parties indulged with rich resources readily exploitable for teaching provided that they invested time and effort to search and to apply them into use. At the same time, each individual learner surely has to be the side who should jointly contribute to determining the success of learning. To succeed in exploiting the ICT gadgets for learning, teachers play their directing, guiding and orchestrating roles, while students should be persons of discipline with positive choice and a sense of achievement. By being so, the activities using ICT gadgets will be of a meaningful engagement, as a responsible use of ICT may add up to a sense of creativity in searching for relevant, meaningful, and positive data or information for teaching and learning.

Due to its' resourcefulness, ICT, to a certain extent, is like a jack of all trades,

through which approaches to learning may manifest in such modes as:

a. Drill, where students can do repeated quizzes or exercises for certain language skills.

b. Simulation, in which students can pretend to perform a certain role following a real life model observable via computer screen or self-recording facilities. Body language, facila expressions, and accuracy of pronunciation may be benefited from

using this mode.

c. Games, which are available off and on line, may serve as a means for students to train both mental and physical endurance following a certain instruction to do sport, socio drama, and social duties.

d. Online learning tutorial or e-learning resources, a modular learning model which is much adopted by open access and distance learning. In this mode, computer provides 
informations pertaining to a certain topic of learning subjects readily accesible to be understood or to be responded to.

e. Test/Quizz, by which students can independently and ideosyncratically do self-assessment on a certain aspect of language skills. Surprisingly, more and more numbers of of websites these days made different quizzes available for free access to students. Even, some types of of tests have been equipped with answer keys and instant feedback of test outcomes.

f. Online discussion forums. For those passionately participating in an online discussion, they are easily connectable to other people on a large number of lists of discussions on a wide range of subject areas.

g. Consultant and information source. With the greater and more powerful capacity of servers, computer technology is currently capable of providing gargantuan data basis readily traceable by the Internet users. Through Google, students can now make limitless queries that can instantly find unimaginable answers.

h. Information swap. Again the connectivity of the world-wide webs making computers all over the world connectable wire or wirelessly. The web connections allow the users to exchange information (mostly free of charge).

i. Online gigantic library. Unlike people in the past when access to information was so much confined by space and time, people of the digital age are indulged by hands-on sources of information called the Internet which grows bigger every second with new update of information.

Last but not least, communication in education in this current era can be made through different modes such as via telephone, computer, Internet, email, and many new coming social media, making contact and interaction between teachers and students a lot easier. Even in passing through academic information from and to, teachers and students can take advantage of the cyber space.Liu (2012) found that social network sites can provide students 
opportunities to be more independent in their study. Interaction can be virtually done synchronously or asynchronously through the Internet.

Fortunately, language learning, particularly English is one of the best facilitated subjects, in a sense that it has been much benefited from the English as an International lingua franca for people of any nation and walk of life. At the same time, computer application programmes are mostly written in English which is certainly facilitative to English learning. What is more, all four skills of language (speaking, reading, writing dan listening) exersises have been much written on the Net which allow all the users to access and use for free practices.

The key to success of using ICT for language learning lies on three qualities that each learner and teacher has to have, i,e autonomy, capability, and creativity (Lowther et al., 2008). Autonomous in taking control of their own learning or teaching; being capable of using necessary gadgets for appropriate purposes; and is able to create every possible opportunity to learn a new thing. All the three characteristics are necesities to develop good quality teaching and learning with ICT.

\section{ICT and Learning}

Amidst the revolutionary progress and innovation of ICT, the use of media technology in foreign language teaching and learning has constantly evolved in a relatively slow pace. Despite more and more gadget availability, sporadic efforts by teachers to try to make use of the technology such as audio, video, and computers as a part of teaching activities remain noticeably insufficient. Even, when technology has developed a lot faster in the last decades and a lot of technological gadgets are getting more affordable to almost everyone, questions remain hanging over the usability for learning assistance. Although these gadgets are not particularly designed for learning purposes, they contain authentic materials usable for learning, such as learning language. Even when gadgets are used for games or for communication they, as a matter of fact, can potentially be useable for learning.

As cited by Chen (2011) research conducted by Chapelle, 2001; Egbert, Chao, \& Hanson-Smith, 2007; Salaberry, 2001; Zhao, 2003) has shown that the use of technology can broaden the horizons for learning an L2, and also has an impact on the nature of both the acquisition process and the object of study. The use of technology helps learners to expose themselves to English, a language which has been learnt and used by more and more 
speakers. According to David Graddol (in Shyamlee, 2012), digital technologies provide avenues to improving certain skills such as writing, writing and reading, despite posing challenges such as plagiarism and unfair use. Yet still, the potentials remain outweighting the risks so long as their actual wealth is optimally explored.

As a showcase, a previous pilot study involving 112 University students in Semarang, conducted by Suratno, et al. (2013) suggests that all the students of a faculty of Letters, of a private university in Semarang, Indonesia, have made IT gadgets part of their day-to-day life activities. As indicated by the responses of the questionnaire, smart phones have been the most frequently and laptops as their second most frequently-used gadgets. They all enjoy using the technological gadgets and they admit that their vocabulary expands as a result of using them.

In addition, learning through the facilities offered by the Internet, as they admit, is both interesting and engaging. What remains to be answered is how they perceive about the existing technological gadgets they currently can get access to and what kinds of activities they have taken their advantages for, as well as whether they are generally facilitative to learning, especially for English language learning.

In addition to the elaborated potentials, technology offers with it both visual and audial comfort and indulgence to its users. The more the newcoming technology comes with novelties, the broader the chances to explore and to exploit for the improved qualities. Both teachers and learners have a lot more opportunities to invest time for innovative learning and teaching. This certainly provides challenges for anyone committed to technolgical use, as it requires them to keep doing whatever is necessary to constantly investigate and find the answer to the questions as to how to make the most of the technological gadgets for optimal teaching and learning.

Truly genuine endeavour has to be done through research which is expected to provide inputs to the world of education, particularly that of the English language, so that all the persons in charge of the policy making positions are conviced that indeed ICT gadgets will persistently evolve to be richer facilities for learning which will be capable of changing and shapping a more rosy facet of education. 


\section{METHODS OF DATA COLLECTION AND ANALYSIS}

In this research, the researcher views the research object partly as being separate and independent of the investigator, as first of all it attempts to know how research respondents in this survey perceive the reality of the ICT gadgets. Yet, at the same time the data to be collected involve respondents' opinions about their hands-on experience on the use of the gadgets. Given such natures, the researchers considers that a mixed-method should be the appropriate approach to undertanding the phenomena being investigated. This way, this endeavour is expected to be capable of answering the research questions.

The primary rationale supporting the use of mixed method is the amalgamation of both quantitative and qualitative data into a single end of continuum (Creswell, 2009:840). To be more precise, researcher aims to embed the secondary data (qualitative data) to the primary data (quantitative). The second reason is that such an amalgamation allows the researcher to triangulate the research findings (Rossman \& Wilson, 1994; Creswell, 2003). Triangulation (Patton, 2001) refers to an attempt to look for research consistency which is, in this particular research, also intended to delve deeper into the very nature of the data so that both can be functionally complementary to each other in minimizing the pitfalls of a mere reliance on a single method (Creswell, 2003).

\section{A. Population and Sample}

The total research subjects of 400 students from 4 public and 4 private schools were selected randomly to fill out the survey questionnaire consisting of various statements relevant to the respondents' perceptual beliefs about ICT, statements specifically designed to know the extent ICT has been used in day-to-day life activities of the students both inside and outside classroom, as well as descriptive statements pertaining to language learning-related activities. Whilst schools and participants were intentionally balanced between public and private to maintain non-bias portrayal of the phenomena, sex, in this research, was not particularly considerd as a significantly determining aspect in the data collection and analysis. Upon completion of the survey, an FGD (Focus Groups Discussion) was held involving five to 10 students per school institution to gather the information concerning their real experiences with ICT gadgets ownership. 


\section{B. Data Collection}

To obtain the data, researcher administered a survey questionnaire to the selected respondents. The instrument for this study was purposively designed close-ended in nature rather than open-ended, given that the purpose is to provide a descriptive quantitative analysis. For each of the statements in the instrument, participants were requested to choose answers based on Likert scale of Strongly Agree, Agree, Disagree, Strongly Disagree for garnering information on the perception about the ICT gadgets, whilst for the rests of the questionnaire, to establish frequency, Rarely, Sometimes, Often, and Very Often were available options to choose from. The analyzed tapescripts of the FGD was then taken as supporting data.

\section{Data Analysis}

Data were analyzed descriptively using SPSS statistical software to determine the Mode, Mean and the SD (Standard Deviations) as the statistical parameters of the analysis needed to generalize the findings. Specifically for determining the respondents' perception, the lower the Mode suggests the less positive their perception and vice versa. Similarly for the rest of the questionnaire, the lower the Mean suggests the less important the item of the questionnaire, or suggests the less frequent use of the ICT gadgets for particular activities as defined in the wordings of the questionnaire and vice versa. Whilst, Standard Deviation is a statistical measure to determine the breadth the data dispersion are distributed. Data from the FGD was analyzed topically to establish the consistency of the survey questions.

\section{Establishing Validity and Reliability}

Prior to data analysis, research instrument was piloted to 20 high school students to establish the validity and the reliability (the consistency of the instrument) of the questionnaire needed to determine the efficacy of the instrument (Creswell, 2003), so that the results of which were expected to improve the wording, the scales, and the format of the questionnaire, in addition to establishing content validity. In the post-piloting stage, instrument of the research was revised for readiness of administration. 


\section{DATA ANALYSIS AND DISCUSSION}

\section{A. Quantitative Analysis}

The validity of the pre-data collection was conducted to test the 62 items of questionnaire by comparing the counted $r$ value and $r$ table. The $r$ table of (.05) is 0.359 . This means $95 \%$ items of questionnaire were valid. As for two (2) invalid items, revision has been made by simplifying the wording of the questionnaire. The reliability test indicates that $r$ table at $(.05)$ is 0.359 , while the value of Alpha is $\mathbf{0 . 9 5 7}$, meaning that the standard of consistency of the instrument is very well met.

\section{B. Perception}

From the graph below, $71.5 \%$ respondents chose 3, meaning that they perceived that technological gadgets indeed are useful for the day-to-day life, and $21.3 \%$ respondent perceived them very positively. There are only $7 \%$ respondents have negative perception.

\section{Table 1}

\section{The Mean of Respondent' Perception}

\section{Statistics}

Transformed data

\begin{tabular}{lll}
\hline $\mathrm{N}$ & Valid & 400 \\
\cline { 2 - 3 } & Missing & 0 \\
\hline Mean & 3,1325 \\
\hline Mode & 3,00 \\
\hline Std. Deviation &, 56190 \\
\hline
\end{tabular}

Having been transformed, the statistical data show that the Mean of the perception of the respondents is relatively high which is higher than 3.1 suggesting that all respondents perceive the ICT gadgets positively. 
Suratno, A. \& Aydawati, E.N., Exploring Students' Perception and ICT Use

Table 2

The Valid Percent of the Respondent' Perception Mean

Transformed data

\begin{tabular}{|c|c|c|c|c|c|}
\hline & & Frequency & Percent & Valid Percent & $\begin{array}{l}\text { Cumulative } \\
\text { Percent }\end{array}$ \\
\hline \multirow[t]{5}{*}{ Valid } & 1,00 & 6 & 1,5 & 1,5 & 1,5 \\
\hline & 2,00 & 22 & 5,5 & 5,5 & 7,0 \\
\hline & 3,00 & 285 & 71,3 & 71,3 & 78,3 \\
\hline & 4,00 & 87 & 21,8 & 21,8 & 100,0 \\
\hline & Total & 400 & 100,0 & 100,0 & \\
\hline
\end{tabular}

The Mean as indicated in the previous table is further described by the valid percent of the data distribution where majority, i.e. 71.3 and 21.3 percents of the respondents subsequently perceive positively and very positively. There is only 7 percent of them who has negative perception. The above data detribution is more visible through te presentation of the graph below.

Figure 1

Graph of Perception

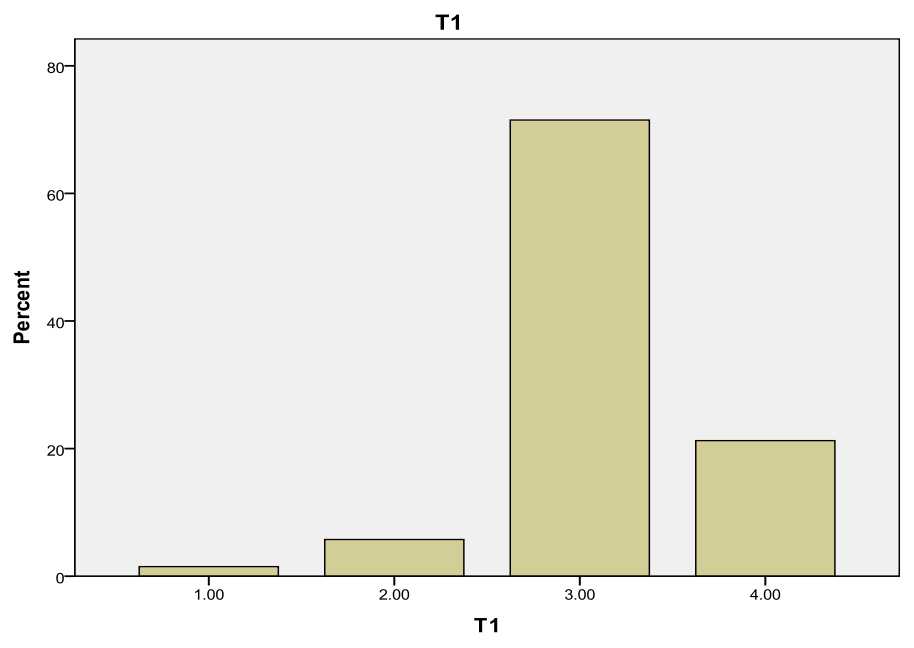


As detailed in the methodology chapter, this survey instrument managed to gather information about sex (male-female) and school status (public and private). This provides necessary information as regards how perception of the respondents is different as it is cross-tabulated across the two groups. The statistical crosstabulation produces the general overview of the differences.

Table 3

Crosstabulation Based on Sex

Transformed data * Sex Crosstabulation

Count

\begin{tabular}{|c|c|c|c|c|}
\hline & & sex & & \\
\hline & & males & females & Total \\
\hline \multirow{4}{*}{ Transform 1} & 1,00 & 2 & 4 & 6 \\
\hline & 2,00 & 14 & 8 & 22 \\
\hline & 3,00 & 127 & 158 & 285 \\
\hline & 4,00 & 37 & 50 & 87 \\
\hline Total & & 180 & 220 & 400 \\
\hline
\end{tabular}

The above graph further shows the differences of perception between males and females. However, the differences of data distribution does not in itself clarify the actual perceptual difference because the number of respondents were not equally distributed between the sex. So, it means that males and females tend to perceive similarly given the proportion of the number of the respondents.

The graph below illustrates the tendency between the crosstabulated data of the sex of the respondents. 
Suratno, A. \& Aydawati, E.N., Exploring Students' Perception and ICT Use in Indonesian High School

Figure 2

Crosstabulation Based on Sex

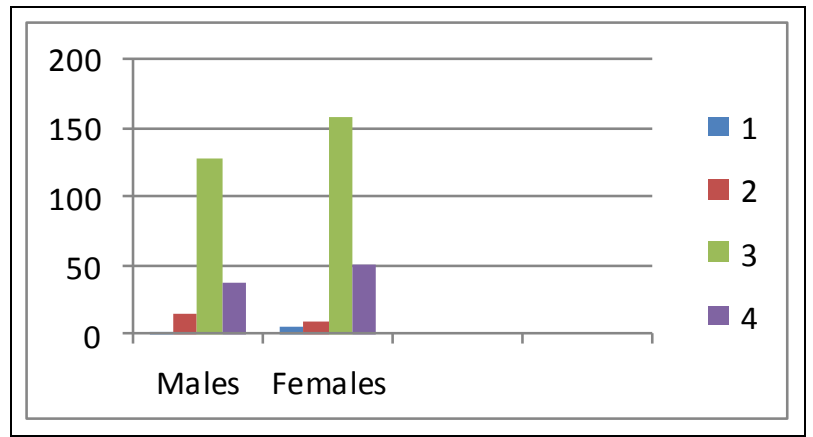

Table 4

Crostabulation Based on Public and Private Schools

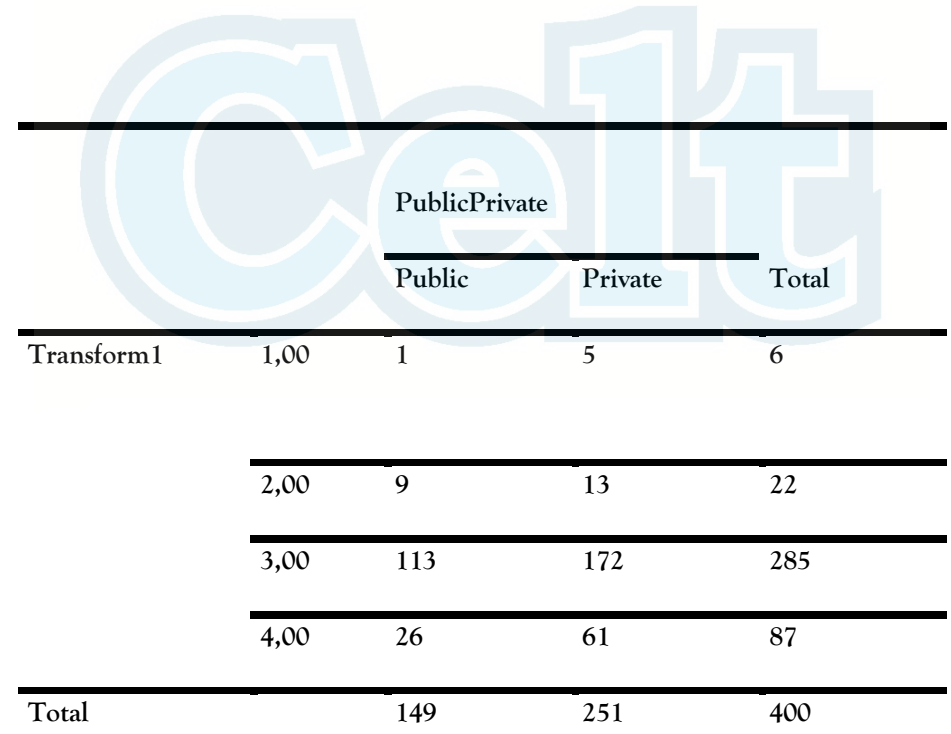


192 Celt, Volume 16, Number 2, December 2016, pp. 177-200

Figure 3

\section{Crosstabulation Based on School Status}

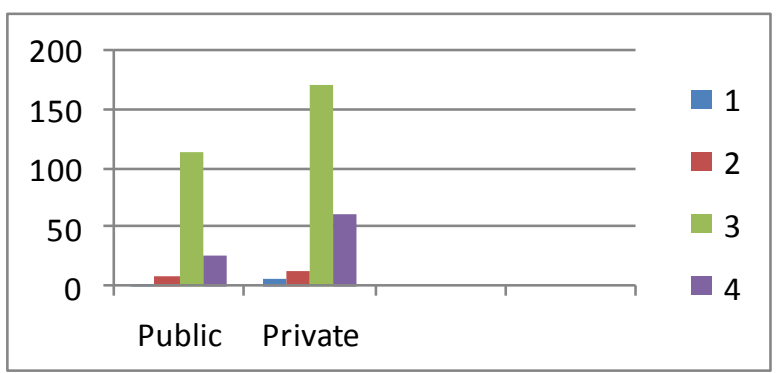

Just like the previous crosstabulated data, the respondents from both public and private schools also shows similar tendency in a sense that they have similar pattern. It is evident from the graph that despite the inequal number, participants from both institutions have similar perception.

\section{The general use of gadgets}

As can be seen in the table below, among the most frequent use of the ICT gadgets are for on line chatting and social media activites, checking the dictionary and encyclopedia, and searching the Internet for practical information and learning-related information search, exploring and using softwares, and watching and downloading activities.

Table 5

The Modus Value of the Outside-School Use statistics

\begin{tabular}{|c|c|c|c|c|c|c|c|c|c|c|c|c|}
\hline & 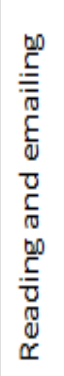 & $\begin{array}{l}n \\
\stackrel{n}{\pi} \\
\frac{5}{U} \\
0 \\
0\end{array}$ & $\begin{array}{l}\infty \\
\stackrel{5}{0} \\
0 \\
0 \\
0 \\
\alpha \\
n \\
z \\
z \\
z \\
z\end{array}$ & 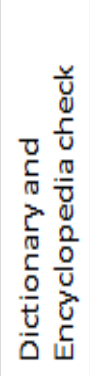 & 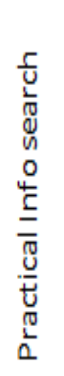 & 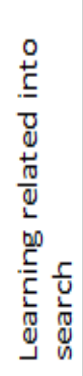 & 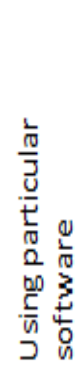 & 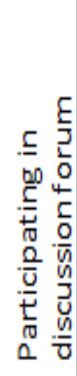 & 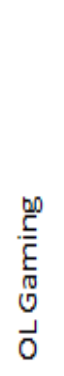 & 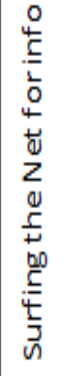 & 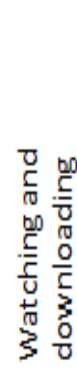 & 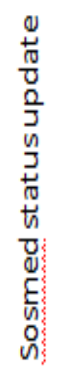 \\
\hline Valid & 400 & 400 & 400 & 400 & 400 & 400 & 400 & 400 & 400 & 400 & 400 & 400 \\
\hline Missing & 0 & 0 & 0 & 0 & 0 & 0 & 0 & 0 & 0 & 0 & 0 & 0 \\
\hline Mode & 2.00 & 3.00 & 3.00 & 3.00 & 3.00 & 3.00 & 3.00 & 2.00 & 2.00 & 3.00 & 3.00 & 3.00 \\
\hline
\end{tabular}


Three activities which have less portion of time allocation are reading and eamailing, on line gaming, participating in on line discussion forum. How they, overall suggest that ICT gadgets have been used for various positive activities despite variation of frequencies.

\section{Specific School-Related Use of ICT Gadgets}

The table below presents the data of the students' use of ICT gadgets for activities realated to day-to-day school activities. Table 3 indicates that the use of ICT is predominantly for leisure instead of academic. This is vindicated by predominant Modus of 2 of the respondents' reponses. Conclusion that can be drawn from this section is that there has not enough attempt made at both an individual or institutional level to optimize the wealth of the educational technological gadgets.

The fact that substandard infrastructure for ICT provision as well as the insufficient effort to sytematically exploit the gadgets for a well-planned and well-organized fashion might also be a reason why students have not used or rarely used them for academic activities. Activites such as communicating via email with the teachers, the rare participation on on line learning, the less frequent collecting and saving necessary information for learning purposes confirm the above claim.

\section{Table 6}

\section{Value of Modus of Academic Use}

statistics

\begin{tabular}{|c|c|c|c|c|c|c|c|c|c|c|c|c|c|c|c|}
\hline & 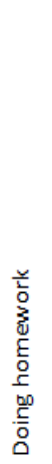 & 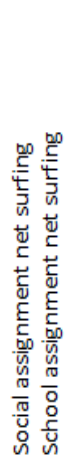 & 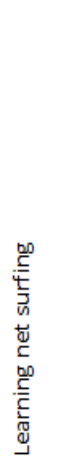 & 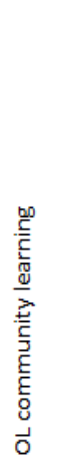 & 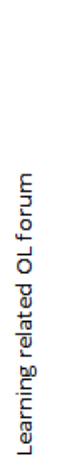 & 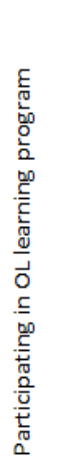 & 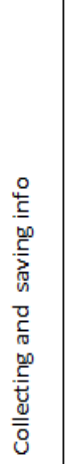 & 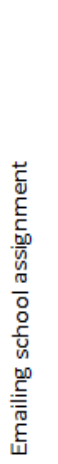 & 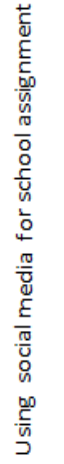 & 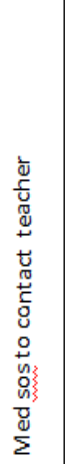 & 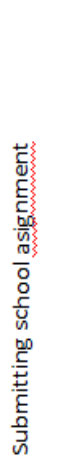 & 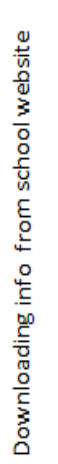 & 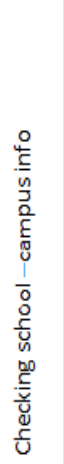 & 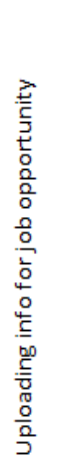 & 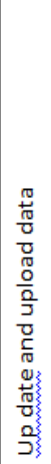 \\
\hline Valid & 400 & 400 & 400 & 400 & 400 & 400 & 400 & 400 & 400 & 400 & 400 & 400 & 400 & 400 & 400 \\
\hline Missing & 0 & 0 & 0 & 0 & 0 & 0 & 0 & 0 & 0 & 0 & 0 & 0 & 0 & 0 & 0 \\
\hline Mode & 3.00 & 3.00 & 3.00 & 1.00 & 2.00 & 2.00 & 2.00 & 2.00 & 2.00 & 3.00 & 2.00 & 3.00 & 2.00 & 2.00 & 2.00 \\
\hline
\end{tabular}


194 Celt, Volume 16, Number 2, December 2016, pp. 177-200

\section{E. ICT Gadgets for Learning English}

The mean value is 2.5 within the standard deviation of 0.75 , meaning that respondents have their gadgets but have yet to use them for activities relevant to learning English purposes. This, at the same time, indicates that despite the availability of the gadgets, the use for learning English remains average or insufficiently taken to its optimum advantage.

Table 7

Mean Value of the Gadgets Use for Learning English

Descriptive Statistics

\begin{tabular}{|c|c|c|c|c|c|}
\hline & $\mathrm{N}$ & $\begin{array}{c}\text { Minim } \\
\text { um }\end{array}$ & $\begin{array}{l}\text { Maxi } \\
\text { mum }\end{array}$ & Mean & $\begin{array}{c}\text { Std. } \\
\text { Deviatio } \\
\mathrm{n}\end{array}$ \\
\hline Use gadgets to & 400 & 1.00 & 4.00 & 2.6200 & .76293 \\
\hline $\begin{array}{l}\text { improve Ena. learning } \\
\text { OL Video to improve } \\
\text { listening }\end{array}$ & 400 & 1.00 & 4.00 & 2.2800 & .77660 \\
\hline $\begin{array}{l}\text { OL Quiz Audio to } \\
\text { improve listening }\end{array}$ & 400 & 1.00 & 4.00 & 2.2000 & .77233 \\
\hline $\begin{array}{l}\text { Non-Quiz OL Audio to } \\
\text { improve listening }\end{array}$ & 398 & 1.00 & 2.00 & .2864 & .26306 \\
\hline OL Grammar & 400 & 1.00 & 4.00 & 2.1700 & .81410 \\
\hline $\begin{array}{l}\text { OL Vocabulary } \\
\text { Exercise }\end{array}$ & 400 & 1.00 & 4.00 & 2.3175 & .84468 \\
\hline OL Reading Exercise & 400 & 1.00 & 4.00 & 2.2075 & .80689 \\
\hline $\begin{array}{l}\text { OL Voice Recorder } \\
\text { for Pronunciation }\end{array}$ & 400 & 1.00 & 4.00 & 2.0325 & .81123 \\
\hline $\begin{array}{l}\text { Email for Writing } \\
\text { Practice }\end{array}$ & 400 & 1.00 & 4.00 & 2.1625 & .87636 \\
\hline $\begin{array}{l}\text { Sosmed Chatting for } \\
\text { Practicinq Enqlish }\end{array}$ & 400 & 1.00 & 4.00 & 2.9025 & .87459 \\
\hline $\begin{array}{l}\text { Download English } \\
\text { Info learning }\end{array}$ & 400 & 1.00 & 4.00 & 2.5625 & .87636 \\
\hline $\begin{array}{l}\text { resources } \\
\text { Receiving and } \\
\text { sending messages in } \\
\text { English }\end{array}$ & 400 & 1.00 & 4.00 & 2.5150 & .82855 \\
\hline $\begin{array}{l}\text { Uploading English } \\
\text { info to the net }\end{array}$ & 400 & 1.00 & 4.00 & 2.3125 & .91484 \\
\hline $\begin{array}{l}\text { Accessing Video } \\
\text { delivered in English }\end{array}$ & 400 & 1.00 & 4.00 & 2.3925 & .96476 \\
\hline $\begin{array}{l}\text { English discussion } \\
\text { Forum }\end{array}$ & 400 & 1.00 & 4.00 & 1.9850 & .83157 \\
\hline $\begin{array}{l}\text { Searching info written } \\
\text { in Enclish }\end{array}$ & 400 & 1.00 & 4.00 & 2.5975 & .81680 \\
\hline Valid N (listwise) & 398 & & & & \\
\hline
\end{tabular}


The opportunities that the ICT gadets offer for improving English language skills such as reading, writing, listening, grammar quizzes, vocabulary expansion have not frequently and purposively taken.

\section{F. Discrepancies}

From the qualitative data analysis, it is noticeable that respondents know how beneficial the ICT gadgets is for their day-to-day life. This excerpt illustrates it.

K: Do you think ICT gadgets are useful for you?

D: Ooo certainly. Very beneficial. Yes, supposing you don't have dictionary with you, or you are lazy to bring hard copy books, you just need to search the need you will find what you want. There are plenty you can explore in the Net. You can find references easily, journal or whatever you want.

For the useability of ICT gadgets for learning English, the FGD participantss clearly indicate that they know that there a lot to get exploitable from the ICT gadgets. These are their responses.

K: What can you amagine the ICT gadgets can do to help you learn and improve your English. What do you think you can benefit from it?

W: A lot, such as looking up a disctionary, also there are a lot of applications useable for improving our English.

D: For our English learning purposes, we can watch video on You Tube, as there are a lot spoken in English. That way we can learn speaking and listening. We can read articles written in English, so we can expand our vocabulary.

K: Very very useful and helpful.

From the last part of the FGD, we notice that there has been inconsistency of participants' direct responses and the responses of survey questions where the statistical Mean of the ICT gadgets use for learning English were relatively low all over, contrast with their aknowledgement about its importance for English learning assistance. Thus there has been discrepancies between the knowledge about the use and the actual practice of 
day-to-day use. They tend to infrequently use the gadgets for consciously learning English

Script of FGD suggests that the answer to FGD questions was consistent with the survey result in that ICT gadgets are most popularly used for social media activities, gaming, communicating, whilest less so for systematic use of learning. If there is any effort to use for learning purposes, it tends to be done sporadically by individual learner which vary from person to person. This means that the optimal use of the ICT gadgets for learning, especially for learning English, is not yet achieved. This opens up an opportunity to use it for optimum use should school institution or even higher level of authority, such as policy makers in the national or reginal levels, begin to systematically do make an effort to produce a comprehensive plan to take ICT more seriously by making policies of integration into curriculum complete with clear gudelines and detail of implementation.

From there, a conclusion can be drawn that despite their effort to use ICT gadgets fpr learning English, the systematic and regular use for learning has not taken place. This might be because demand and stimulus to do so coming students' external parties such as institution, teachers, and conducive academic environment has not yet been in existent.

Another discrepancy disclosed from the FGD was that infrastructural aspects of ICT both in the provision of gadgets and the quality of the Internet connection was realized to be far from sufficient and presentable. Some participants even expressed their griefance about how access to the Internet which is supposedly open to all turns out to be exclusively accessible only to limited few people even with passwords made known to only prevellege few. What is more, when they are lucky to get access, the quality of connection is extremely poor and under-standard. It means that the surveyed school institutions, for one or another reason, have been unaware of possibly ignored the prevalent mismatched policies in their respective establisments.

FGD also unleases findings that very few respondents either together in group or individually have taken the advantages of the ICT gadgets for learning English. Some said they only began to learn English only when their English teacher asked to do so. From there we can say that there is still conspicuously a wide gap between the advancement of ICT and the the supposedly functional use of it for learning. For one, the reason for that is the poor standard quality of technological insfrastructures, and for another is the non-existence of necessary sub-system to support learning to happen. In other 
words, a systematic effort and willingness to exploit technological-based materials and to get them integrated into English language teaching and learning is still very low. It is not the students who do not know and want to maximize for learning but instead learning enviroments which are not conducive to their learning.

An important contribution that this research has made, among other things, is that the final destination of the ICT gadgets for optimal use of learning will eventually very much depend on the creation of precondition for learning both in terms of infrastructure and sub-system. In order for decent learning to take place, it demands that each individual school institution provide minimum infrustructure needed to support learning and the real creation of the sub-systems in the form of compatible policies supporting the integration of ICT gadgets into school curricula, which means that decision makers in the local, regional, and national levels are the ones to start with to be followed by the strategy for ICT trainings and classroom implementation.

\section{CONCLUSIONS}

The research respondents, irrespective of the sex and school status, perceived the ICT gadgets positively as vindicated by the survey and FGD results and that the respondents have generally used the ICT gadgets for activities of necessity such as on line chats, reading news, using disctionaries and encyclopedia, searching for information, downloading and watching videos, and the most populair one is using it for social media activities. In spite of being in the generally underfacilitated school environments, students have individually made use of the ICT gadgets positively. Respondents have exploited them, however erratically, for such a wide range of purposes including to support learning. Unfortunately as indicated by the moderatly low accumulative Mean scores and the results of FGD which managed to discover the generally poor sub-standard quality of ICT infrastructure and the non existence of supporting sub-sytems at schools, therefore, we can conclude that the prime reasons respondents have not taken advantage of the ICT gadgets to specially use for improving and learning English, such as reading, writing, listening, grammar quizzes, vocabulary expansion is not the lack of knowledge about the potential contribution the ICT can make for learning English but rather the prevalent institutional policy mismatch. To cope with it, a real action by both policy makers and institutonal levels to start changing policies on ICT integration into the school curricula is barely unpostponable. 


\section{SUGGESTIONS}

The analysis reveals that ICT gadgets bring with them the substantial potentials should they be optimized for learning through systematic and purposeful activities properly designed by school learning-related activities. The problem, therefore, lies on the extent to which the school policy makers, or school curriculum designers would consider integrating the ICT into the school curricula through explicit, structured and measurable classroom activities. With that in mind the researchers would suggest that anyone concerns with the strategic importance of ICT to take it seriously for the best possible advantage of the future activities of learning and teaching.

In order for convincing that the suggestion this research has made gains stronger basis, another research investigating the extent each individual institution has started integrating ICT into teaching and learning English has to be done. So, an observation and interview with the school principals and English teacher would be of meaningful research instruments.

\section{REFERENCES}

Avram, R., \& Tami, D. (2004). The impact of ICT on education: the three opposed paradigms, the lacking discourse. Retrieved July 14, 2007, from http://www.informatik.uniremen.de/ ${ }^{\sim}$ mueller/kr004/ressources/ict_im pact.pdf.

Benson, P. \& Lor, W. (1999). Conceptions of language and language learning. System, 27, 459-72.

Brush, T., Glazewski, K. D. \& Hew, K. F., (2008). Development of an instrument to measure preservice teachers' technology skills, technology beliefs, and technology barriers. Computers in the Schools, 25, 112-125.

Castro Sánchez, J. J. \& Alemán, E. C., 2011. Teachers' opinion survey on the use of ICT tools to support attendance-based teaching. Journal Computers and Education, 56, 911-915.

Chen, C.L.A. (2011). Extended Implications of Technology in Learning. Columbia University Working Papers in TESOL \& Applied Linguistics, 11 (2), 27-29. 
Creswell, J. (2003). Research design: Qualitative, quantitative and mixed methods approaches $\left(2^{\text {nd }}\right.$ ed.). Thousand Oaks, CA: SAGE Publications Computer-enhanced language learning (pp. 1-13). Alexandria, VA: TESOL.

Creswell, J.W. (2009). Research design: Qualitative, quantitative, and mixed methods approaches. (3rd ed.). Los Angeles, CA: Sage.D.Shyamlee, S. (2012). use of technology in English language teaching and Learning: An Analysis. 33.

Creswell, J.W. (2003). Research design: Qualitative, quantitative, and mixed approaches. Thousand Oaks, CA: Sage.

Ellis, R. (2008). Learner Beliefs and Language Learning. Asia TEFL Journal, 10 (4): Conference Proceedings.

Kompas.com (2016) Pengguna Internet di Indonesia Capai 132 Juta. Saturday, 290ktober2016.

http://tekno.kompas.com/read/2016/10/24/15064727/

2016.pengguna. internet.di.indonesia.capai.132.juta.

Liu, Y. (2010). Social Media Tools as a Learning Resource. Journal of Educational Technology Development and Exchange, 3 (1), 101-104.

Lowther, D. L., Inan, F. A., Strahl, J. D. \& Ross, S. M., 2008. Does technology integration work when key barriers are removed Educational Media International, 45, 195-213.

Ministery of Information and Communication (2014). Pengguna Internet Indonesia

Capai

82

Juta.https://kominfo.go.id/index.php/content/detail/3980/

Kemkominfo\%3A+Pengguna+Internet+di+Indonesia+Capai+82+Juta/

O/berita_satker

Patton, M.Q. (2001). Qualitative Research and Evaluation Methods. Thousand Oaks, CA: Sage Publications.

Robbins, S., P. (2003). Perilaku Organisasi, Jilid I. Jakarta: PT Indeks Kelompok Gramedia.

Rossman, G. \& Wilson, B. (1994). Numbers and words revisited: being shamelessly eclectic. Quality and Quantity, 28, 315-327. 
200 Celt, Volume 16, Number 2, December 2016, pp. 177-200

Rüschoff, B. (1993). Language Learning and Information Technology State of the Art Keynote Address CALICO '92 International Symposium Bridges'. CALICO Journal, 10 (3).

Shyamlee, S. (2012). Use of technology in English language teaching and learning: An analysis. A paper presented at the 2012 International Conference on Language, Medias and Culture, Singapore.

Suratno, A. (2014). Students' Perceptual Beliefs about the Information Technology for Language Learning. (presented in 80th TEFLIN Seminar).

Walgito, B. (1991). Psikologi Sosial, Yogyakarta: Yayasan Penerbit Fakultas Psikologi Universits Gajah Mada.

Warschauer, M. \& Healey, D. (1998). Computers and language learning: an overview. Language Teaching, 31, 57-71. doi:10.1017/S0261444 800012970. 